\title{
Investigating late Holocene variations in hydroclimate and the stable isotope composition of precipitation using southern South American peatlands: an hypothesis
}

\author{
T. J. Daley ${ }^{1}$, D. Mauquoy ${ }^{2}$, F. M. Chambers ${ }^{3}$, F. A. Street-Perrott ${ }^{4}$, P. D. M. Hughes ${ }^{5}$, N. J. Loader ${ }^{4}$, T. P. Roland ${ }^{5}$, \\ S. van Bellen ${ }^{2}$, P. Garcia-Meneses ${ }^{1}$, and S. Lewin ${ }^{1}$ \\ ${ }^{1}$ School of Geography, Earth and Environmental Sciences, Plymouth University, Drake Circus, Plymouth, PL4 8AA, UK \\ ${ }^{2}$ School of Geosciences, University of Aberdeen, Elphinstone Road, Aberdeen, AB24 3UF, UK \\ ${ }^{3}$ Centre for Environmental Change and Quaternary Research, School of Natural and Social Sciences, Francis Close Hall, \\ University of Gloucestershire, Cheltenham, GL50 4AZ, UK \\ ${ }^{4}$ Department of Geography, College of Science, Swansea University, Swansea, SA2 8PP, UK \\ ${ }^{5}$ School of Geography and the Environment, University of Southampton, Southampton, SO17 1BJ, UK
}

Correspondence to: T. J. Daley (tim.daley@plymouth.ac.uk)

Received: 31 January 2012 - Published in Clim. Past Discuss.: 20 February 2012

Revised: 16 August 2012 - Accepted: 21 August 2012 - Published: 20 September 2012

\begin{abstract}
Ombrotrophic raised peatlands provide an ideal archive for integrating late Holocene records of variations in hydroclimate and the estimated stable isotope composition of precipitation with recent instrumental measurements. Modern measurements of mean monthly surface air temperature, precipitation, and $\delta \mathrm{D}$ and $\delta^{18} \mathrm{O}$-values in precipitation from the late twentieth and early twenty-first centuries provide a short but invaluable record with which to investigate modern relationships between these variables, thereby enabling improved interpretation of the peatland palaeodata. Stable isotope data from two stations in the Global Network for Isotopes in Precipitation (GNIP) from southern South America (Punta Arenas, Chile and Ushuaia, Argentina) were analysed for the period 1982 to 2008 and compared with longer-term meteorological data from the same locations (1890 to present and 1931 to present, respectively). $\delta \mathrm{D}$ and $\delta^{18} \mathrm{O}$-values in precipitation have exhibited quite different trends in response to local surface air temperature and precipitation amount. At Punta Arenas, there has been a marked increase in the seasonal difference between summer and winter $\delta^{18} \mathrm{O}$-values. A decline in the deuterium excess of summer precipitation at this station was associated with a general increase in relative humidity at $1000 \mathrm{mb}$ over the surface of the Southeast Pacific Ocean, believed to be the major vapour source for the local precipitation. At Ushuaia, a fall in $\delta^{18} \mathrm{O}$-values was
\end{abstract}

associated with an increase in the mean annual amount of precipitation. Both records are consistent with a southward retraction and increase in zonal wind speed of the austral westerly wind belt. These regional differences, observed in response to a known driver, should be detectable in peatland sites close to the GNIP stations. Currently, insufficient data with suitable temporal resolution are available to test for these regional differences over the last $3000 \mathrm{yr}$. Existing peatland palaeoclimate data from two sites near Ushuaia, however, provide evidence for changes in the late Holocene that are consistent with the pattern observed in modern observations.

\section{Introduction}

\subsection{A role for peatland palaeoclimate studies in southern South America}

The strength and location of mid-latitude westerly weather systems are essential determinants of regional climate in both the Northern $(\mathrm{NH})$ and Southern $(\mathrm{SH})$ Hemispheres. Recently demonstrated linkages between changing Arctic seaice cover, the spatial variability of the northern polar jet and consequent intra-annual temperature and precipitation variability (Petoukhov and Semenov, 2010) imply that improved 
understanding of the long-term variability of the westerlies is a critical research priority because of their influence over key agroclimatic variables such as atmospheric water balance and soil moisture availability. The modern climatology of the SH westerlies is well-constrained both in terms of strength and location (Garreaud, 2009; Garreaud et al., 2009). There is a clear linkage between near-surface $(850 \mathrm{hPa})$ zonal wind strength and precipitation amount (Garreaud, 2007; Garreaud et al., 2009). Of particular interest is the evidence that the mean annual latitude of the core $\mathrm{SH}$ westerlies has changed through the late 20th and early 21st centuries (Thompson and Solomon, 2002; Marshall, 2003). The latitude of the zonal wind maximum at $300 \mathrm{hPa}$ has shifted southwards through the period 1968-2001, with reduced wind speeds being observed between 35 and $55^{\circ} \mathrm{S}$ and increased wind speeds between 55 and $70^{\circ} \mathrm{S}$ (Garreaud, 2007; Garreaud et al., 2009). This poleward retraction of the westerlies was associated with an increase in the positive phase of the Southern Annular Mode (SAM) (Kidson, 1999; Gong and Wang, 1999; Limpasuvan and Hartmann, 1999; Marshall, 2003; Jones et al., 2009). The SAM is a principal mode of variability in the atmospheric circulation of the SH, associated with synchronous anomalies in surface air pressure over Antarctica and the southern mid-latitudes (Gong and Wang, 1999; Marshall, 2003). Oceanic carbon models indicate that SH climate variability, including that linked to variations in the SAM, may significantly influence the oceanic carbon cycle and airsea $\mathrm{CO}_{2}$ fluxes in temperate and high latitudes (Le Quéré et al., 2007). Whilst it has been suggested that this latitudinal displacement of the westerlies may have been related to increasing greenhouse gases and/or ozone depletion (Thompson and Solomon, 2002; Toggweiler and Russell, 2008), variations in SH sea-ice extent (Kidston et al., 2011) or solar forcing (Varma et al., 2011), uncertainty remains over its impact on atmospheric $\mathrm{CO}_{2}$ drawdown by the Southern Ocean (Le Quéré et al., 2007).

Improved understanding of the drivers of variability in the strength and position of the SH westerlies necessarily relies on robust, synchronised, well-calibrated and continuous datasets. However, longer-term (centennial to millennialscale) proxy records of variability in these parameters are scarce. Only three proxy-climate records with high temporal resolution are available for southern South America between $20^{\circ} \mathrm{S}$ and $55^{\circ} \mathrm{S}$, with the longest spanning only $\sim 780 \mathrm{yr}$ (Neukom et al., 2011). Ice core and dendroclimatological data offer excellent and well-dated records for the recent past, but existing Andean ice core records for southern Patagonia/Tierra del Fuego only extend back to 1965 AD (Vimeux et al., 2009). Similarly, the longest currently available dendroclimatological reconstruction for the region starts at $1650 \mathrm{AD}$ (Boninsegna et al., 2009). Relatively new lake cores have begun to extend these reconstructions further (Moy et al., 2008; Moreno et al., 2009), but there remains a pressing need to link the instrumental record appropriately to a widely distributed, accurately dated, continuous and longer term palaeoarchive in order to test the timing and sign of climatic responses at multi-decadal to centennial timescales.

Peatlands can provide that missing link (Chambers et al., 2012). Raised bog hydrology is particularly sensitive to the length of the summer water deficit (Charman, 2007; Charman et al., 2009). Peatlands respond to changes in meteoric conditions through the effect of the atmospheric moisture balance (precipitation-minus-evaporation) on their water table depths (Barber and Langdon, 2007; Charman, 2007; Charman et al., 2009). Southern South American peatlands, therefore, are perfectly placed to record long-term changes in the SH westerlies, given that wind intensity affects precipitation mainly produced in winter by fronts and low-pressure systems embedded in the prevailing westerly circulation (Rojas et al., 2009). The Island of Tierra del Fuego, in particular, is situated in the dominant path of the southern westerlies during austral summer and is well-suited for studies of past variations in their latitude and intensity. The ombrogenous bogs of Tierra del Fuego provide high-resolution records of past climate (Pendall et al., 2001) because their water table levels are closely coupled to the atmospheric moisture balance (Charman, 2007; Charman et al., 2009). As with many proxy archives, raised bogs provide a somewhat complex record, in this case, of precipitation-minus-evaporation rather than a pure temperature or precipitation signal. Furthermore, peat-based climate records need to be carefully analysed to distinguish the palaeoclimatic signal from autogenic ecohydrological feedbacks (Barber, 1981; Swindles et al., 2012), but with appropriate sampling, many studies have shown that raised bogs can be used successfully to identify regional climatic change (Barber et al., 1994, 1998; Langdon et al., 2003; Blundell and Barber, 2005; Hughes et al., 2006; Charman et al., 2006; Daley and Barber, 2012). With these considerations appropriately taken, the high peat accumulation rates of $\sim 5-10 \mathrm{yr} \mathrm{cm}^{-1}$ (Pendall et al., 2001; Mauquoy et al., 2004; Chambers et al., 2007) permit sub-decadal resolution of environmental changes over multi-millennial timescales. Furthermore, the peat records are continuous and overlap with the instrumental record, enabling the vital comparison of palaeodata with meteorological observations. The suitability of peatlands is further demonstrated by their wide range of proxy indicators. In addition to the reconstruction of palaeohydrology, the southern South American peat archives have provided data on regional vegetation changes (Markgraf, 1993), fire regimes (Huber et al., 2004), pollution loading (Biester et al., 2002; Martínez Cortizas et al., 2007), dust loading (Sapkota et al., 2007; Björck et al., 2012) and explosive volcanism (Kilian et al., 2003).

\subsection{The nature of peatlands in Tierra del Fuego}

Much of our systematic understanding of the palaeoclimate information that can be drawn from these archives has been derived from studies of European and North American peat systems (Barber et al., 1994; van Geel and Renssen, 
1998; Hughes et al., 2006; Charman, 2007). The microrelief elements (hummocks, lawns, and hollows) of the raised Sphagnum bogs in Tierra del Fuego resemble European and North American examples. The range of $\mathrm{pH}$-values recorded from pool microforms in these bogs ( $\mathrm{pH} 4.3-4.6)$ is also consistent with those recorded from Northern Hemisphere Sphagnum raised bogs (Mataloni, 1998). The largest area in South America in which these ombrotrophic peat bogs are found coincides with the distribution of Nothofagus pumilio (Lenga) deciduous forests (Moore, 1983), which receive an annual precipitation of 400-800 $\mathrm{mm}$ (Roig et al., 1996). This peatland type is dominated by Sphagnum magellanicum with Empetrum rubrum, Carex magellanica, Gunnera magellanica, Marsippospermum grandiflorum, Gaultheria pumila, Rostkovia magellanica and Tetroncium magellanicum (Coronato et al., 2006). Raised Sphagnum bogs, dominated by Sphagnum magellanicum with Donatia fascicularis, Oreobolus obtusangulus, Schoenus andinus, and Senecio trifurcates occur in the evergreen forest zone (Nothofagus betuloides) to the south and west of Tierra del Fuego (Moore, 1983) where annual precipitation totals reach up to $\sim 4000 \mathrm{~mm}$. Two Sphagnum raised bogs $\sim 30 \mathrm{~km}$ from Ushuaia, Isla Grande, Tierra del Fuego, have been described by Mark et al. (1995). Their surfaces are raised between 4 and $6 \mathrm{~m}$ above the surrounding land surface, and the niche of Empetrum rubrum resembles its Northern Hemisphere equivalent, Empetrum nigrum, in that it is restricted to drier (hummock) microforms. Shrubs of Nothofagus antarctica (nirre) and the rush Marsippospermum grandiflorum characterize the crests of hummocks. Pools 3-60 m long are generally arranged in parallel crescentic lines and are similar to those on mires in southern New Zealand. Fringing these pools, Sphagnum fimbriatum has been recorded. The diversity of Sphagnum species in Fuegian bogs is lower than on European and North American peat bogs, and their surfaces may be entirely covered by Sphagnum magellanicum, extending from high hummocks (which can exceed $1 \mathrm{~m}$ in height) to pool margins. The wide range of water table depths that Sphagnum magellanicum occupies in Tierra del Fuegan bogs is similar to the broad habitat niche that it displays in Northern Hemisphere peatlands.

\subsection{An ideal archive for combined hydroclimate and water isotope analysis}

Whilst the dominance of a single, relatively eurytopic Sphagnum species may prove problematic for a palaeoclimate investigation by plant macrofossil analysis, it provides the ideal opportunity for Sphagnum cellulose stable isotope analysis (Pendall et al., 2001; Chambers et al., 2007). Isotopic investigation of southern South American peat archives was pioneered in the 1990s (White et al., 1994; Pendall et al., 2001) and later followed by palaeohydroclimatic studies (Mauquoy et al., 2004; Chambers et al., 2007). Early work on peatland stable isotopes in bulk samples from NW European sites revealed very large amplitude variations in measured isotope values (Brenninkmeijer et al., 1982; Dupont and Brenninkmeijer, 1984; van Geel and Middeldorp, 1988). This arose, in part, as a result of the sampling of both vascular and non-vascular plant species. The different internal water transport mechanisms in these contrasting floral groups produced two quite separate populations of isotope data (Brenninkmeijer et al., 1982; Ménot-Combes et al., 2002). Hence, variations in the ratio of vascular to non-vascular species through these records masked more subtle changes in the source water isotope signal. The dominance of Sphagnum magellanicum in Tierra del Fuego, however, permitted isolation of Sphagnum and the first genus-specific isotope records to be published (White et al., 1994; Pendall et al., 2001). For these early pioneers, the sample sizes required for stable isotope measurement were $\sim 5 \mathrm{~g}$, requiring the use of large samples of bulk peat. Recent advances in the use of continuous-flow isotope-ratio mass spectrometry have made it possible to measure $\delta^{18} \mathrm{O}$ and $\delta^{13} \mathrm{C}$ by high temperature pyrolysis (and $\delta \mathrm{D}$ via the additional procedure of nitration or online equilibration) (Gehre and Strauch, 2003; Filot et al., 2006) on cellulose samples that are typically of $0.3-0.35 \mathrm{mg}$ dry weight (Boettger et al., 2007). Analysis of the cellulose fraction of preserved sub-fossil Sphagnum remains has recently been shown to provide reconstructions of the past isotopic composition of precipitation (Daley et al., 2009, 2010). So, understanding of the modern Sphagnum isotope system and analytical technology are both now sufficiently advanced to permit development of new high-resolution palaeoclimate records for southern South America.

\subsection{The importance of $\delta_{\text {precipitation }}\left(\delta_{\mathrm{p}}\right)$ and deuterium excess in climatology}

Records of past changes in the isotopic composition of precipitation $\left(\right.$ palaeo- $\left.\delta_{\mathrm{p}}\right)$ are rarely either simple palaeothermometers or palaeo-rain gauges (Araguás-Araguás et al., 2000; Daley et al., 2011). Rather, they are primarily indicators of changes in the rain-out history of air masses (Cole et al., 1999; Araguás-Araguás et al., 2000). The isotopic composition of precipitation $\left(\delta_{\mathrm{p}}\right)$ is controlled by isotopic fractionation during the movement of water molecules through the hydrological cycle (Dansgaard, 1964). Hence, the isotopic labelling of precipitation actually reflects complex factors in the hydrological system that include atmospheric conditions over the ocean surface in the vapour source area, the stable isotope composition of surface seawater, the seasonality of precipitation and evaporative effects, as well as the condensation temperature of precipitation (Siegenthaler and Oeschger, 1980; Rozanski et al., 1992, 1993; Jouzel et al., 1997; Cole et al., 1999; Araguás-Araguás et al., 2000; Darling and Talbot, 2003). $\delta_{\mathrm{p}}$ and temperature are closely associated at high latitudes (Leuenberger et al., 1999; Jouzel et al., 2000, 2007). Towards lower latitudes, however, this correlation becomes weaker (Araguás-Araguás et al., 2000). The coastal regions of the northern mid-latitudes of both Europe 
and North America experience a large annual variation in $\delta^{18} \mathrm{O}_{\mathrm{p}}$ (e.g. $\sim 15 \%$ at Truro, Nova Scotia, and Cuxhaven, northern Germany) (IAEA/WMO, 2004) in response to a variety of factors including variations in moisture source, temperature of atmospheric condensation and amount of rainfall (Rozanski et al., 1993; Darling and Talbot, 2003). The equivalent latitudes in southern South America experience a similar amplitude of annual variability in $\delta^{18} \mathrm{O}_{\mathrm{p}}$ (e.g. $\sim 10 \%$ at Ushuaia and $\sim 20 \%$ at Punta Arenas) (IAEA/WMO, 2004), despite a noticeably narrower annual temperature range $(\sim$ $30^{\circ} \mathrm{C}$ at Truro, Nova Scotia, and $\sim 20^{\circ} \mathrm{C}$ at Cuxhaven versus $\sim 10^{\circ} \mathrm{C}$ at Ushuaia) (IAEA/WMO, 2004): implying a greater influence of mean moisture source and precipitation amount.

Disentangling the factors affecting the stable isotope signature of precipitation is aided by calculation of the deuterium excess $(d)$, given by the formula $d=\delta \mathrm{D}-8\left(\delta^{18} \mathrm{O}\right)$. Variations in $d$ relate most strongly to variations in atmospheric conditions over the vapour source region (Dansgaard, 1964; Merlivat and Jouzel, 1979; Gat, 1980; Sonntag et al., 1983; Rozanski et al., 1993). Hence, past changes in deuterium excess may indicate changes in the source area for local precipitation. Relatively high positive values of $d(>10)$ are characteristic of moisture originating from surface evaporation in an environment with relatively low humidity and/or high wind speeds and/or relatively warm ocean temperatures. Values $<10$ indicate a moisture source that is considerably more humid and/or with relatively cool surface water temperatures. It has been estimated that a $10 \%$ increase in relative humidity over the ocean will decrease deuterium excess by $\sim 6 \%$ (Rozanski, 1985).

\subsection{Development of an hypothesis}

Recent work from North American and NW European peatlands has indicated a clear linkage between mid- to late Holocene hydroclimatic variations and changes in the reconstructed isotopic composition of precipitation (Daley et al., 2009, 2010). The topography and climatology of Tierra del Fuego, however, is quite different from these examples (Fig. 1). Indeed, orography has been identified as the most significant factor controlling the spatial distibution of $\delta_{\mathrm{p}}$ in southern South America (Stern and Blisniuk, 2002). The interaction of Andean topography with the dominant westerlies results not merely in strong spatial variations in precipitation amount but also in the development of an isotopic rain shadow, such that higher $\delta_{\mathrm{p}}$-values are observed on the windward side of the Andes and lower $\delta_{\mathrm{p}}$-values on the leeward side, in addition to an altitude effect (Rozanski, 1995; Stern and Blisniuk, 2002). It is reasonable to hypothesise that, in a region where the climate is so strongly affected by changes in precipitation patterns, spatial variations in bog surface wetness (BSW) and the isotopic composition of the precipitation source water over time should reflect changes in the $\mathrm{SH}$ westerly wind belt. So, given that increased zonal flow at $850 \mathrm{hPa}$ in the late twentieth and early twenty-first centuries

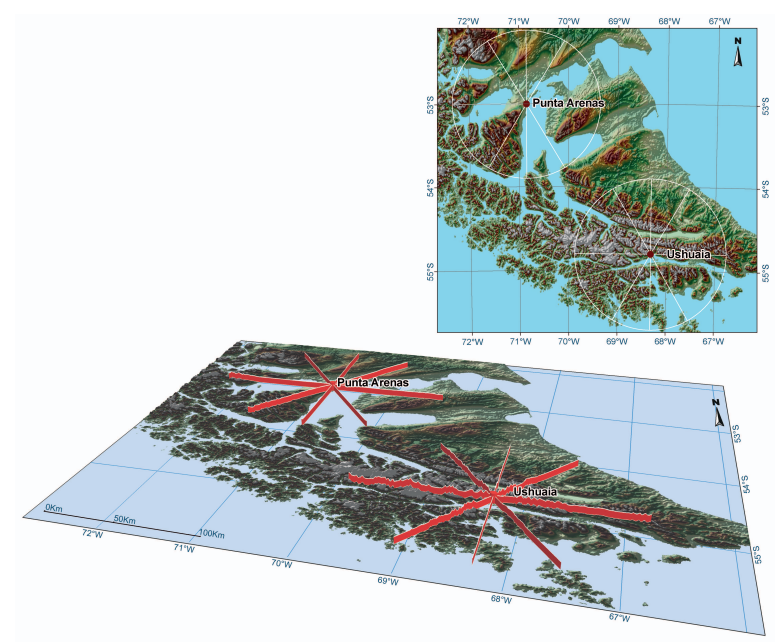

Fig. 1. Topographic map of the study region derived from NASA STRM 90 m Digital Elevation Data (available at: http://srtm.csi. cgiar.org/). Punta Arenas, Chile, and Ushuaia, Argentina, are labelled. Extending from each city are $100 \mathrm{~km}$-long radial "ribbons" that highlight vertical topography in directions of N, NE, E, SE, S, SW, W and NW. Data are projected using Lambert conformal conic projection with a central meridian of 70 degrees west and standard parallels at 5 and 42 degrees south. This projection has correctly described the form of the study region at the expense of introducing distortion in the representation of bearings from the two sampling points illustrated. The open seawater within the $100 \mathrm{~km}$ radius of Punta Arenas is visibly clear.

has led to an observed amplification of the rain shadow effect of the Andes in the mid-latitudes (Garreaud, 2007, 2009), there should have been a corresponding change in the regional distribution of oxygen and hydrogen isotopes in precipitation (meteoric waters) (Stern and Blisniuk, 2002). Here, we investigate the isotopic signature of this observed variation using data from the GNIP database. We use these data to derive hypotheses for how past changes in the wind belt would be reflected in the peatland archive if the same mechanisms were operational. Finally, we test these hypotheses using the currently available peat-based palaeohydrological and palaeo-isotope records from Tierra del Fuego covering the last $\sim 3000 \mathrm{yr}$.

\section{Modern variations in the isotopic composition of precipitation $\left(\delta_{\mathbf{p}}\right)$ and meteorological parameters}

\subsection{Instrumental data sources}

Southern South America is reasonably well-covered by meteorological stations that have recorded the isotopic composition of precipitation since the late twentieth century. The data from these stations were collected and archived according to IAEA standard protocols and are available via the Global Network for Isotopes in Precipitation (GNIP) 
database (IAEA/WMO, 2004). We have focused our analysis of these instrumental records on sites that fall within the same latitudinal and longitudinal ranges as those peatlands that are suitable for palaeoclimate investigation. Two records are of sufficient length to cover at least decadal-scale variation: Punta Arenas, Chile $\left(53^{\circ} 0^{\prime} \mathrm{S}, 70^{\circ} 30^{\prime} \mathrm{W}, 37 \mathrm{~m}\right.$ a.s.l.; 1990 2008; Fig. 1), and Ushuaia, Argentina $\left(54^{\circ} 46^{\prime} \mathrm{S}, 68^{\circ} 16^{\prime} \mathrm{W}\right.$, 10 m a.s.1.; 1982-2002, Fig. 1). A record from Port Stanley on the Falkland Islands (Las Malvinas; $51^{\circ} 42^{\prime} \mathrm{S}, 57^{\circ} 52^{\prime} \mathrm{W}$ ) is available but only covers the 1960 s. From the raw monthly measured values of $\delta \mathrm{D}_{\mathrm{p}}$ and $\delta^{18} \mathrm{O}_{\mathrm{p}}$, and the associated total monthly precipitation in any month, we have calculated the amount-weighted values of $\delta \mathrm{D}$ and $\delta^{18} \mathrm{O}$ for each year or season (summer: December-February, DJF; and winter: June-August, JJA) for which data are available from either Punta Arenas or Ushuaia. In some parts of the records, this is something of a challenge given their discontinuous nature (Table 1). For instance, in the second decade of the records from Ushuaia (1990-2000), occasional missing months prevented the calculation of either an annual or seasonal values for some years, despite the availability of several intermittent months of data. Nonetheless, where an annual amountweighted value can be derived, it is our contention, in the absence of more detailed measurements of growth rate in Sphagnum mosses, that this represents a reasonable estimation of the isotopic value of the precipitation source water that would have been "sampled" by Sphagnum moss growing contemporaneously. This inference is valid given: (1) that empirical evidence has demonstrated that Sphagnum mosses, under sufficiently humid conditions, will grow at mean temperatures in excess of $\sim 4{ }^{\circ} \mathrm{C}$ (Clymo and Hayward, 1982; Clymo, 1984); (2) that the mean monthly air temperature for both Punta Arenas and Ushuaia exceeds $4{ }^{\circ} \mathrm{C}$ for much of the year; and (3) that evidence for continuous annually accumulating growth has been observed previously in oxygen isotopic data from living Sphagnum collected from a peat bog located within a NW European oceanic climate (Daley et al., 2010), where conditions are similar to those in the locations selected here.

Longer meteorological time series are available for the same two locations from the WMO network. For Punta Arenas, monthly surface air temperature and precipitation measurements exist for 1888 to 1993 . For Ushuaia, these variables are available for 1931 to 1993. In the records from both sites, the WMO data and GNIP data overlap sufficiently to verify consistency of measurements through 2008 and 2002, respectively. Use of these longer time series provides the context against which we assess any apparent trends in the stable isotope data.

\subsection{Modern climate of Punta Arenas and Ushuaia}

Mean monthly surface air temperatures and precipitation amounts for the period 1961 to 1990 for Punta Arenas and Ushuaia are presented in Fig. 2 (grey bars and closed circles).
These data are also summarised in Table 1. At both locations, the monthly mean maximum temperature occurred during January with mean temperatures of 10.1 and $9.4^{\circ} \mathrm{C}$, respectively (Table 1 ). Monthly minimum temperatures occurred during July with values of 5.1 and $5.7^{\circ} \mathrm{C}$, respectively (Table 1). Mean annual precipitation was slightly higher at Ushuaia ( $480 \mathrm{~mm}$ compared with $372 \mathrm{~mm}$; Table 1). The seasonal distibution of precipitation was similar at both locations, with more precipitation falling in autumn than in any other season (Fig. 2). A comparison with data from the three most recent decades (1981-2010) (Fig. 2) shows little change in the 30-yr mean for air temperature (open circles), but a slight increase in precipitation amount (grey squares) at both sites. The increase in precipitation was greater at Punta Arenas than at Ushuaia. The seasonal distribution of precipitation has remained similar from 1961 to 1990.

\subsection{Modern $\delta \mathrm{D}$ and $\delta^{18} \mathrm{O}$-values of precipitation}

Biplots of measured monthly $\delta \mathrm{D}_{\mathrm{p}}$ and $\delta^{18} \mathrm{O}_{\mathrm{p}}$ values during the 1980s through to the early 2000s are presented for Punta Arenas and Ushuaia in Fig. 3. Also shown are mean monthly temperature and precipitation amounts in relation to the oxygen isotopic composition of precipitation. No statistically significant relationship between precipitation or temperature and $\delta^{18} \mathrm{O}_{\mathrm{p}}$-values exists at either site (Fig. 3), confirming the complexity of the precipitation isotope signal in this region.

The global meteoric water line (GMWL; Craig, 1961) relates measured values of $\delta \mathrm{D}$ and $\delta^{18} \mathrm{O}$ in meteoric waters on a global scale (black dashed line in the upper left panels of Fig. 3 for each site). The equation for the GMWL is $\delta \mathrm{D}=8\left(\delta^{18} \mathrm{O}\right)+10$. Deviations of measured waters from this line can be used to infer information about the environmental processes that acted to "label" those waters. For both Punta Arenas and Ushuaia, $\delta \mathrm{D}_{\mathrm{p}}$ and $\delta^{18} \mathrm{O}_{\mathrm{p}}$-values for the 1980s and 1990s plot along local meteoric water lines (MWLs) with gradients of 6.1 (Punta Arenas) and 6.4 (Ushuaia) (Fig. 3), noticably lower than that of the GMWL. Three samples were excluded from the calculation of the local MWL at Punta Arenas because of unrealistically positive values in the GNIP database. These may simply be typographical errors. In the absence of more information, however, we have omitted these data, represented by open squares in Fig. 3.

Separation of the data by season (Fig. 3) indicates that the gradient of the local MWL at Ushuaia changes throughout the year (Table 1). Precipitation in austral summer exhibits a low gradient (6.7; Table 1). In contrast, during the winter months, the gradient is steeper than the GMWL (9.0; Table 1). Seasonal variations in the gradient at Punta Arenas are negligible (6.1 and 6.2 for DJF and JJA, respectively; Table 1). The shallow gradients for annual precipitation at Punta Arenas and summer precipitation at Ushuaia are similar to those for waters that fall on a local evaporative line. One possible explanation is that annual precipitation in the last $\sim 20$ to $30 \mathrm{yr}$ has been derived from oceanic sources 
Table 1. Summary table of annual and seasonal meteorological and precipitation stable isotope values for Punta Arenas, Chile, and Ushuaia, Argentina, for the period 1961 to present.

\begin{tabular}{|c|c|c|c|c|c|c|c|}
\hline & & \multicolumn{3}{|c|}{ Punta Arenas } & \multicolumn{3}{|l|}{ Ushuaia } \\
\hline & & & $n$ & $R^{2}$ & & $n$ & $R^{2}$ \\
\hline \multirow[t]{6}{*}{ Annual } & $\operatorname{MAT}\left(1961-1990 ;{ }^{\circ} \mathrm{C}\right)$ & 6.0 & 30 & & 5.7 & 30 & \\
\hline & MAP $(1961-1990 ; \mathrm{mm})$ & 372 & 30 & & 480 & 30 & \\
\hline & Weighted mean $\delta^{18} \mathrm{O}(\%$; using available years, $n$ ) & -8.9 & 5 & & -11.3 & 9 & \\
\hline & Weighted mean $\delta \mathrm{D}(\%$; using available years, $n)$ & -71.8 & 5 & & -86.2 & 9 & \\
\hline & Mean annual $d$ (using available years, $n$ ) & -0.5 & 5 & & 4.4 & 8 & \\
\hline & Mean Annual Meteoric Water Line (MWL) & $\delta \mathrm{D}=6.1\left(\delta^{18} \mathrm{O}\right)-16$ & 194 & 0.94 & $\delta \mathrm{D}=6.4\left(\delta^{18} \mathrm{O}\right)-14$ & 214 & 0.71 \\
\hline \multirow[t]{6}{*}{ Summer } & DJF MT $\left(1961-1990 ;{ }^{\circ} \mathrm{C}\right)$ & 10.1 & 30 & & 9.4 & 30 & \\
\hline & DJF MP (1961-1990; mm) & 92 & 30 & & 127 & 29 & \\
\hline & DJF Weighted mean $\delta^{18} \mathrm{O}(\%$; using available years, $n)$ & -6.8 & 11 & & -10.1 & 16 & \\
\hline & DJF Weighted mean $\delta \mathrm{D}(\% \circ$; using available years, $n)$ & -59.0 & 11 & & -80.6 & 15 & \\
\hline & DJF mean $d$ (using available years, $n$ ) & -4.3 & 11 & & 0.7 & 15 & \\
\hline & DJF Meteoric Water Line (MWL) & $\delta \mathrm{D}=6.1\left(\delta^{18} \mathrm{O}\right)-16$ & 47 & 0.94 & $\delta \mathrm{D}=6.7\left(\delta^{18} \mathrm{O}\right)-13$ & 55 & 0.73 \\
\hline \multirow[t]{6}{*}{ Winter } & JJA MT $\left(1961-1990 ;{ }^{\circ} \mathrm{C}\right)$ & 5.1 & 30 & & 5.7 & 30 & \\
\hline & JJA MP (1961-1990; mm) & 96 & 30 & & 125 & 30 & \\
\hline & JJA Weighted mean $\delta^{18} \mathrm{O}(\%$; using available years, $n)$ & -9.9 & 11 & & -11.8 & 17 & \\
\hline & JJA Weighted mean $\delta \mathrm{D}(\% o$; using available years, $n)$ & -76.2 & 12 & & -86.1 & 16 & \\
\hline & JJA mean $d$ (using available years, $n$ ) & 1.3 & 11 & & 8.6 & 16 & \\
\hline & JJA Meteoric Water Line (MWL) & $\delta \mathrm{D}=6.2\left(\delta^{18} \mathrm{O}\right)-16$ & 45 & 0.91 & $\delta \mathrm{D}=9.0\left(\delta^{18} \mathrm{O}\right)+20$ & 55 & 0.87 \\
\hline
\end{tabular}

with seasonally varying vapour pressure characteristics. For Ushuaia in particular, the MWL is distorted relative to the GMWL by the influence of two quite different end members for moisture source character. Deuterium excess values support the interpretation of a seasonally changing moisture source. Measured monthly, mean d-values vary throughout the year from relatively high values in austral winter to relatively low ones during austral summer (Table 1). Mean summer d-values are -4.3 and 0.7 , whereas mean winter $\mathrm{d}$ values are 1.3 and 8.6, for Punta Arenas and Ushuaia, respectively (Table 1). On an annual basis, the deuterium excess at Punta Arenas is significantly lower than that at Ushuaia. Mean annual $d$ is $-0.5(n=5)$, whereas mean annual $d$ at Ushuaia is 4.4 (Table $1 ; n=11$ ). d-values in precipitation are lower during the summer in mid-latitude coastal regions as a result of the sourcing of moisture from a higherhumidity vapour source. Higher relative surface air humidity reduces the kinetic fractionation of ${ }^{2} \mathrm{H}^{1} \mathrm{H}^{16} \mathrm{O}$ as compared with ${ }^{1} \mathrm{H}^{1} \mathrm{H}^{18} \mathrm{O}$, thereby lowering the deuterium excess (Merlivat and Jouzel, 1979). An adaptation of the model given by Clark and Fritz (1997) is given by the grey dashed lines in the upper left panels of Fig. 3 for each site. The upper (lower) dashed line shows the influence of moisture derived from a drier (more humid) vapour source and demonstrates how a seasonal change in moisture source conditions can yield gradients that are shallower than the GMWL. Summer moisture from sources with higher relative humidity plots closer to the lower dashed line. Winter moisture from sources of lower relative humidity plots closer to the upper dashed line. Whilst feasible for Ushuaia, one drawback of this explanation is that the local MWLs for both seasons at Punta Arenas have similar gradients. An alternative explanation is that the low slope of all the local MWLs (except for Ushuaia in winter), combined with $d<10$, reflects partial evaporation of falling raindrops in the rainshadow area in the lee of the Andes (Rozanski, 1995; Gat, 1996; Friedman et al., 2002b). This would occur throughout the year, but to a greater extent in the summer months, enhancing the seasonal contrast in slope at Ushuaia.

The implications for the reconstruction of the palaeoMWL from combined $\delta \mathrm{D}$ and $\delta^{18} \mathrm{O}$-values from Patagonian peatland Sphagnum cellulose are that, where sufficiently resolved records can be derived, lower gradients than the GMWL in the reconstructed palaeo-MWL should not be unexpected if the isotopic composition of precipitation in the last $\sim 20$ to $30 \mathrm{yr}$ provides a good analogue for changes in the late Holocene. Previously, it might well have been argued that such a gradient in the Sphagnum cellulose isotope data indicated isotopic enrichment by kinetic fractionation (evaporation) of the moss source water before incorporation into the plant via photosynthesis. Now, we should recognise that, for this region, a slope of $<7$ for the reconstructed palaeoMWL would be consistent with modern measurements of meteoric waters.

\subsection{Changes in $\delta \mathrm{D}$ and $\delta^{18} \mathrm{O}$-values of precipitation over time}

Figure 4 shows the time series of amount-weighted average annual $\delta \mathrm{D}$ and $\delta^{18} \mathrm{O}$-values for both GNIP locations (Punta Arenas, Fig. 4b and Ushuaia, Fig. 4e) along with the variations in mean annual precipitation (MAP) (Fig. 4c and f) 

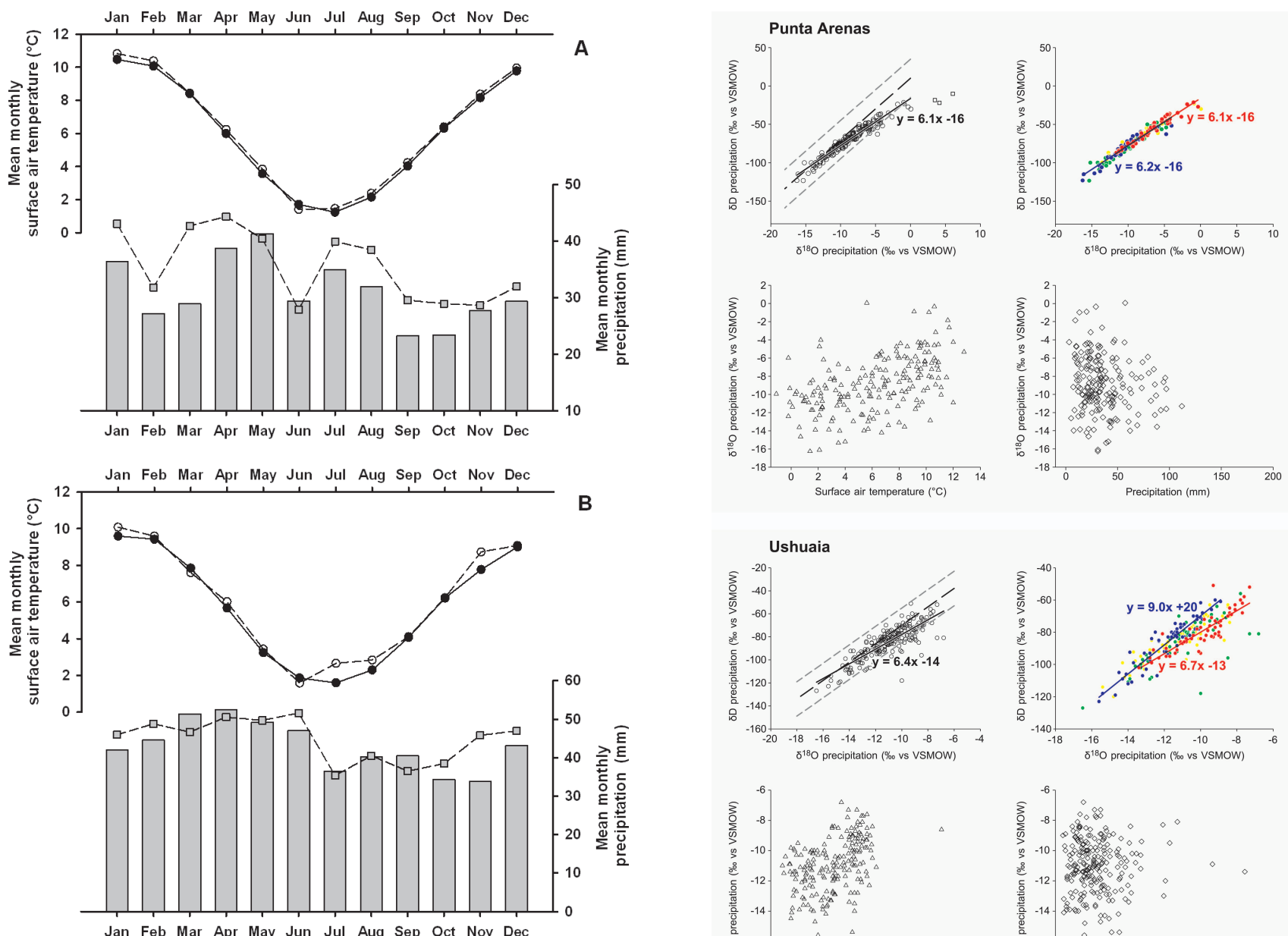

Fig. 2. Mean monthly surface air temperature (MMT; closed circles) and precipitation values (MMP; grey bars) for 1961-1990 at Punta Arenas (A) and Ushuaia (B), compared with MMT (open circles) and MMP (grey squares) for 1981-2010 (see Table 1 for n-values).

and mean annual surface air temperature (MAT) (Fig. 4a and d) since 1888 and 1931, respectively. The incomplete and intermittent nature of the GNIP data, from which occasional monthly values are missing, limits the number of data points to $n=5$ for Punta Arenas and $n=11$ for Ushuaia. Nevertheless, a unidirectional trend towards higher $\delta_{\mathrm{p}}$-values $\left(-10.4 \%\right.$ to $-8.3 \%$ in $\left.\delta^{18} \mathrm{O}\right)$ is observed for Punta Arenas (1996 to 2006), associated with a sequence of years with anomalously high MAT and MAP compared with the 19611990 period. Any temporal trend, however, is not statistically significant given the paucity of data. By contrast, $\delta_{\mathrm{p}}$-values at Ushuaia do not show any evidence for an increasing trend. MAT data are sadly lacking through the period for $\delta_{\mathrm{p}}$-values at Ushuaia. MAP data, however, show evidence for a sequence of years that were wetter than the 1961-1990 average.

Seasonal data provide a more continous and complete data set. Seasonal time series are presented for Punta Arenas and
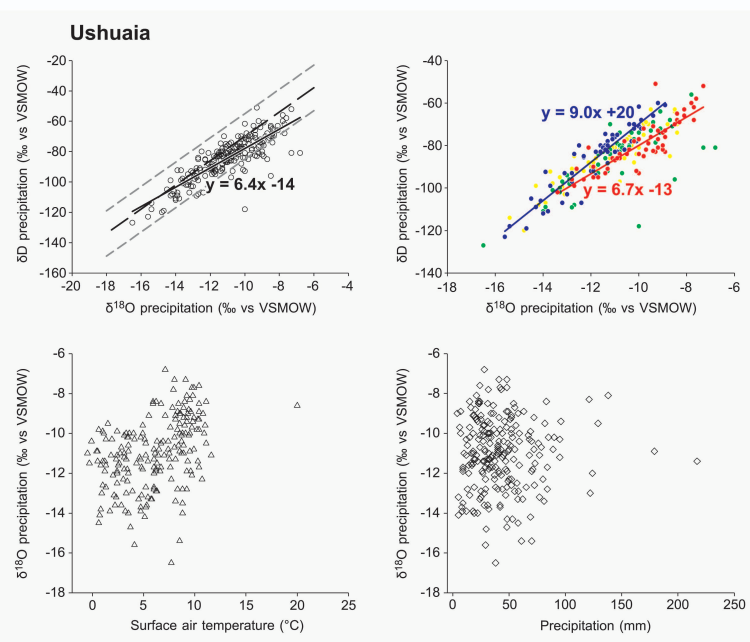

Fig. 3. Modern isotopic and climate data from Global Network of Isotopes in Precipitation (GNIP) (International Atomic Energy Agency-World Meteorological Organization (IAEA/WMO), 2004) stations at Punta Arenas, Chile, and Ushuaia, Argentina. For each site: Upper left graph $=\delta \mathrm{D}$ and $\delta^{18} \mathrm{O}$-values in meteoric waters for 1990-2008 (Punta Arenas) and 1982-2002 (Ushuaia). Local meteoric water lines (MWL) are indicated with solid lines: $\delta \mathrm{D}=6.1\left(\delta^{18} \mathrm{O}\right)-16$ at Punta Arenas, and $\delta \mathrm{D}=6.4\left(\delta^{18} \mathrm{O}\right)-14$ at Ushuaia. Global MWL is given as black dashed line (Craig, 1961). Upper (lower) grey dashed lines indicate meteoric waters from drier (more humid) moisture sources. Upper right graph $=$ variation in isotopic composition of meteoric waters by season (blue circles, June-August; green circles, September-November; red circles, December-February; yellow circles, March-May). Seasonal MWLs are indicated. For Punta Arenas: June-August, $\delta \mathrm{D}=6.2\left(\delta^{18} \mathrm{O}\right)-16$; December-February, $\delta \mathrm{D}=6.1\left(\delta^{18} \mathrm{O}\right)-16$. For Ushuaia: June-August, $\delta \mathrm{D}=9.0\left(\delta^{18} \mathrm{O}\right)+20$; DecemberFebruary, $\delta \mathrm{D}=6.7\left(\delta^{18} \mathrm{O}\right)-13$. Lower left graph $=$ monthly air temperature values and oxygen isotopic composition of monthly precipitation $($ IAEA/WMO, 2004) . Lower right graph $=$ monthly total precipitation values and oxygen isotopic composition of monthly precipitation (IAEA/WMO, 2004). 

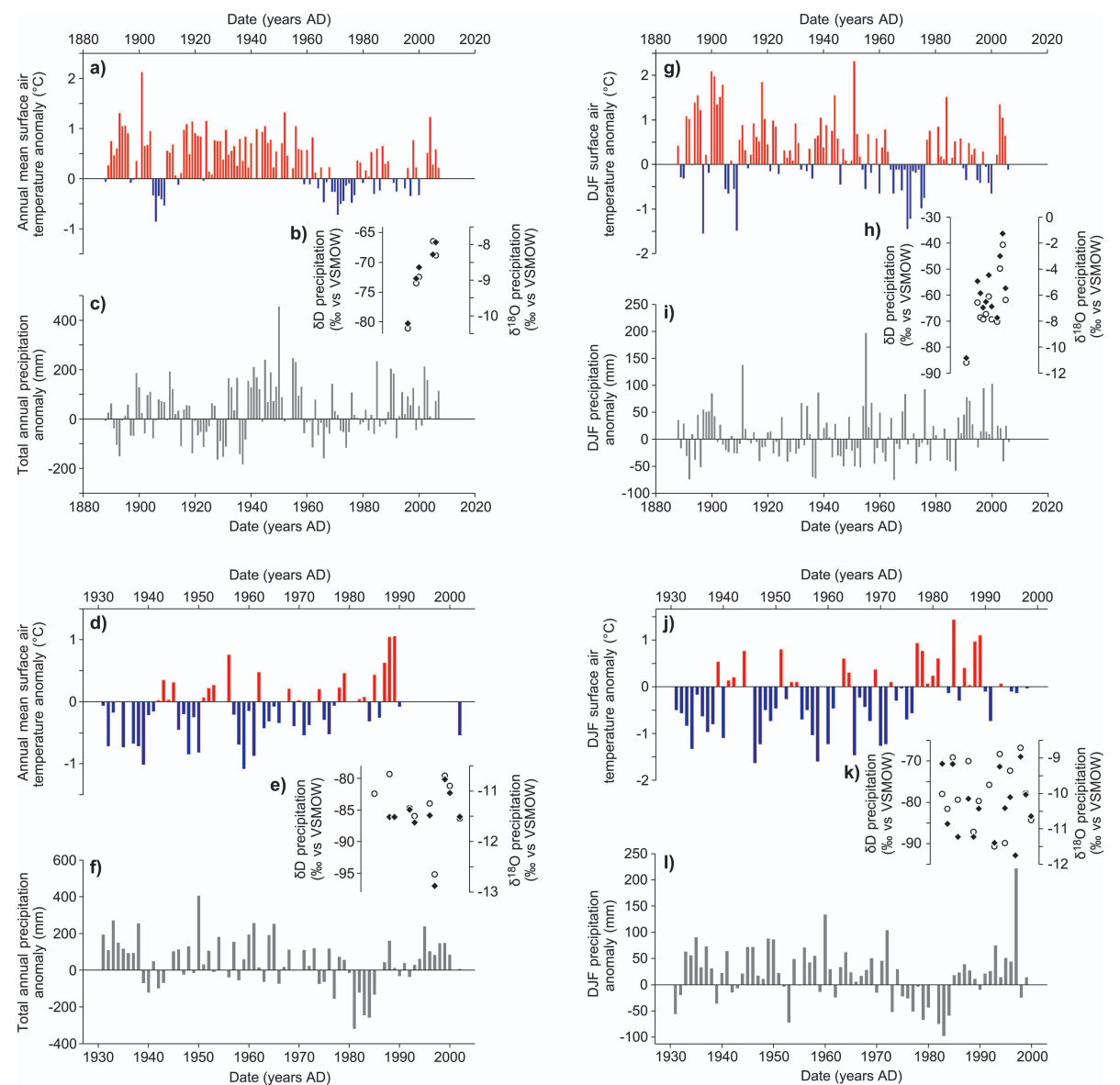

Fig. 4. Modern isotopic and climate timeseries from GNIP/WMO stations at Punta Arenas, Chile, and Ushuaia, Argentina. For Punta Arenas (top graphs): (a) mean annual surface air temperature anomaly $\left({ }^{\circ} \mathrm{C}\right)$ relative to the $1961-1990$ mean. (b) mean annual amount-weighted $\delta \mathrm{D}$ values (open diamonds) and $\delta^{18} \mathrm{O}$-values (open circles) in meteoric waters for years with complete twelve months of data between 1990 and 2008. (c) mean annual precipitation anomaly (mm) relative to the 1961-1990 mean. (g) mean DJF surface air temperature anomaly $\left({ }^{\circ} \mathrm{C}\right)$ relative to the 1961-1990 mean. (h) mean DJF amount-weighted $\delta \mathrm{D}$-values (open diamonds) and $\delta^{18} \mathrm{O}$-values (open circles) in meteoric waters for years with complete DJF sequences of data between 1990 and 2008. (i) mean DJF precipitation anomaly (mm) relative to the 1961-1990 mean. For Ushuaia (bottom graphs): (d) mean annual surface air temperature anomaly $\left({ }^{\circ} \mathrm{C}\right)$ relative to the $1961-1990$ mean. (e) mean annual amount-weighted $\delta \mathrm{D}$-values (open diamonds; linear regression, solid line) and $\delta^{18} \mathrm{O}$-values (open circles; linear regression, dashed line) in meteoric waters for years with complete twelve months of data between 1982 and 2002. (f) mean annual precipitation anomaly $(\mathrm{mm})$ relative to the 1961-1990 mean. (j) mean DJF surface air temperature anomaly $\left({ }^{\circ} \mathrm{C}\right)$ relative to the $1961-1990$ mean. $(\mathbf{k})$ mean DJF amount-weighted $\delta \mathrm{D}$-values (open diamonds) and $\delta^{18} \mathrm{O}$ values (open circles) in meteoric waters for years with complete DJF sequences of data between 1982 and 2002. (l) mean DJF precipitation anomaly (mm) relative to the 1961-1990 mean.

Ushuaia in Fig. 4g-1. DJF precipitation at Punta Arenas exhibited a marked increase in $\delta^{18} \mathrm{O}_{\mathrm{p}}$-values from $-11.2 \%$ to $-2.1 \%$ over the interval 1991 to 2004 (Fig. 4h). The latter value was associated with one of the warmest years during the period of the isotope record. A comparison of the DJF $\delta^{18} \mathrm{O}$-values with those for JJA reveals some interesting differences (Fig. 5). The data appear to indicate a divergence in the mean $\delta^{18} \mathrm{O}$-values of summer and winter precipitation. Whilst a linear regression for the JJA data is not significant, the increase in DJF $\delta^{18} \mathrm{O}_{\mathrm{p}}$-values at Punta Arenas is statistically significant $\left(r^{2}=0.53, P<0.05\right)$.

$\delta_{\mathrm{p}}$-values at Ushuaia during DJF show some evidence for a general decrease between 1982 and 2002 (Figs. 4k and 5b), whilst JJA values trend in the opposite direction (Fig. 5b), although neither relationship achieves statistical signficance based on this amount of data. A fall in DJF $\delta^{18} \mathrm{O}_{\mathrm{p}}$-values associated with increasing amounts of precipitation would be consistent with expectations if annual temperature variability was relatively low, the seasonality of that precipitation had not changed and there was minimal change in the isotopic composition of the surface ocean and the conditions at the moisture source. A link between rising precipitation amount and lower $\delta^{18} \mathrm{O}_{\mathrm{p}}$-values would also be consistent with the literature (Gat, 1980; Rozanski et al., 1993; Araguás-Araguás et al., 2000; Stern and Blisniuk, 2002). 

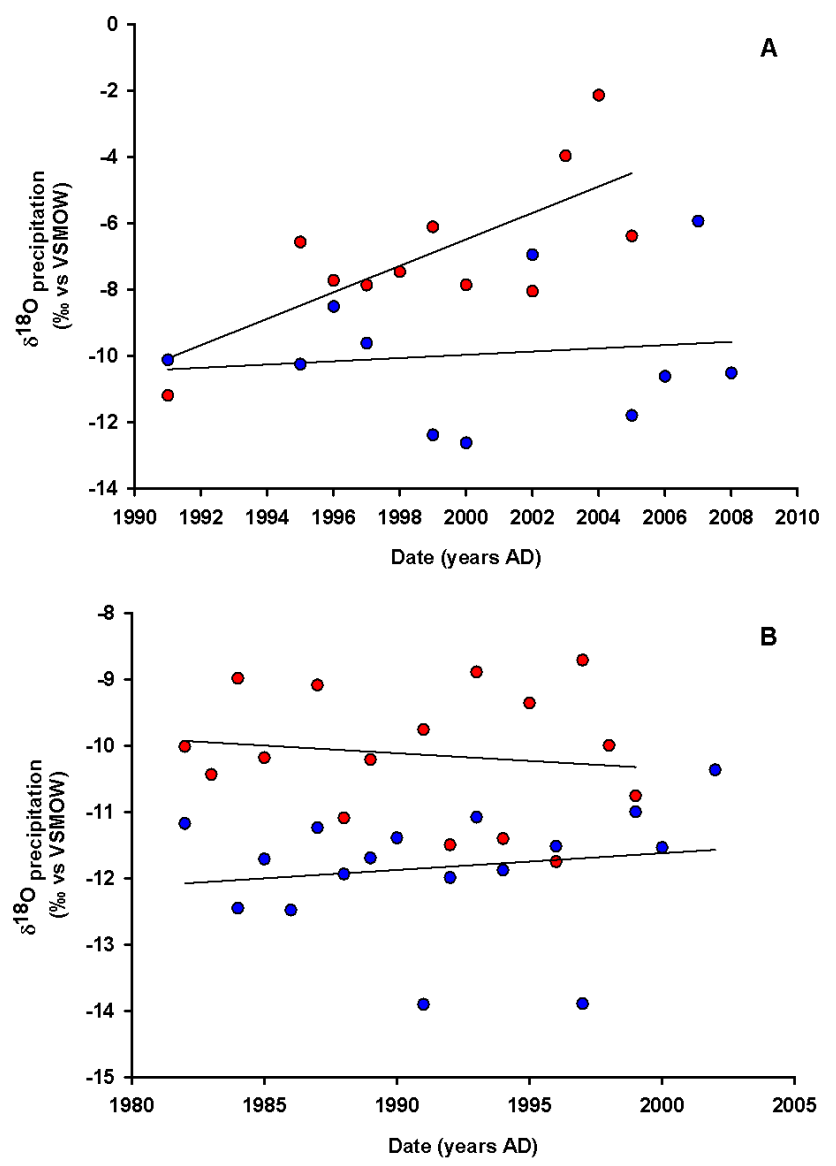

Fig. 5. Comparison of seasonal trends in the mean amount-weighted $\delta^{18} \mathrm{O}$-values in precipitation for Punta Arenas (A) and Ushuaia (B). For Punta Arenas, red dots $=\mathrm{DJF}\left(r^{2}=0.53 ; P<0.05\right)$; blue dots $=\mathrm{JJA}\left(r^{2}=0.01 ; P \gg 0.1\right)$. For Ushuaia, red dots $=\operatorname{DJF}\left(r^{2}=\right.$ $0.02 ; P \gg 0.1)$; blue dots $=$ JJA $\left(r^{2}=0.03 ; P>0.1\right)$.

Variations in the deuterium excess values of DJF and JJA precipitation for 1982 to 2008 are shown in Fig. 6 for Punta Arenas (closed circles) and Ushuaia (open triangles). DJF values (shown in red, Fig. 6) for both sites were consistently lower than JJA values (shown in blue, Fig. 6), indicating a higher average humidity in their moisture source regions in austral summer. d-values of both DJF and JJA precipitation at Punta Arenas declined between 1990 and 2005. Conversely, mean d-values in precipitation at Ushuaia increased over the period 1982 to 2002 . However, none of these trends is statistically significant, with the exception of that for DJF at Punta Arenas $\left(r^{2}=0.64 ; P<0.005\right)$.

Rising $\delta_{\mathrm{p}}$-values associated with a decline in deuterium excess in DJF at Punta Arenas can be explained by reference to NCEP/NCAR reanalysis data. Figure 7 shows 1981-2010 anomalies with respect to the 1961-1990 average for: (a) $1000 \mathrm{mb}$ relative humidity; (b) the $850 \mathrm{mb}$ zonal wind component; and (c) the $850 \mathrm{mb}$ meridional wind component. In the period spanning the measured stable isotope data, zonal
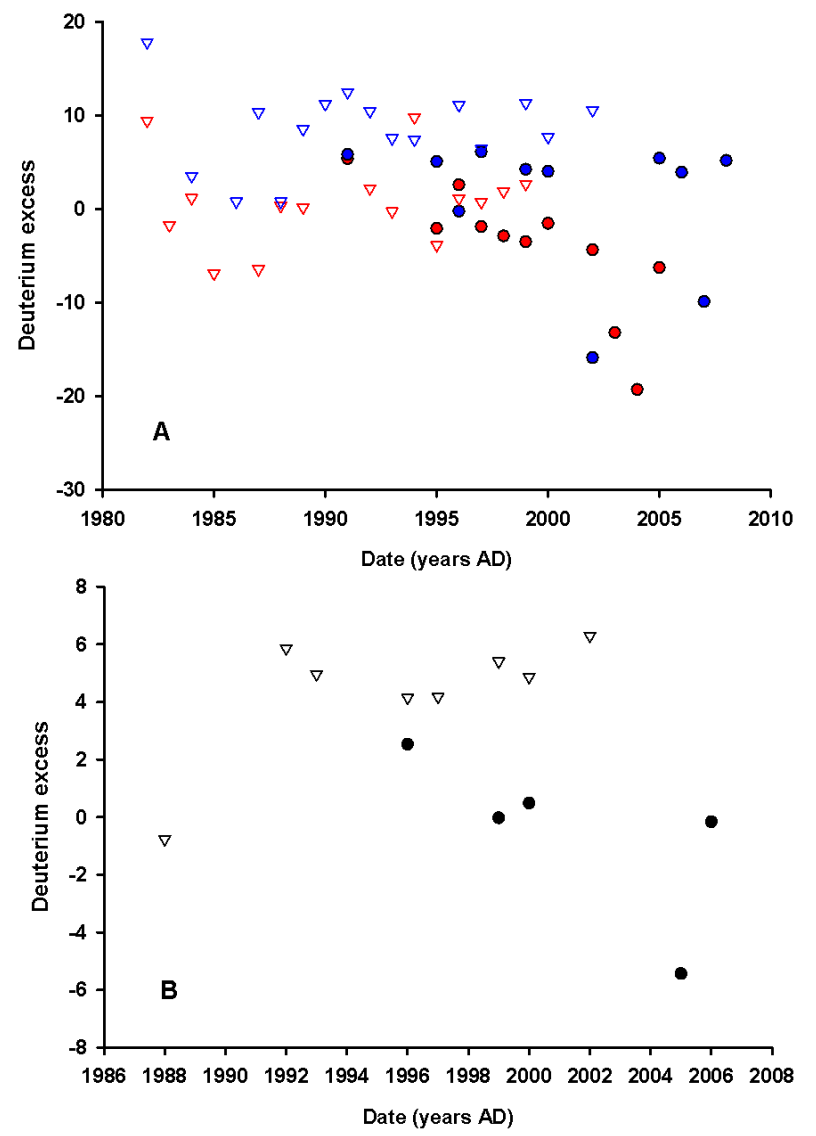

Fig. 6. Seasonal (A) and annual (B) amount-weighted averaged deuterium excess values for Punta Arenas (closed circles) and Ushuaia (open triangles). (A) seasonal d-values, blue = winter (JJA); red =summer (DJF). (B) annual d-values in black symbols. For Punta Arenas, DJF: $r^{2}=0.64, P<0.005$; JJA: $r^{2}=0.08, P>0.1$. For Ushuaia, DJF: $r^{2}=0.02, P>0.1$ ) JJA: $r^{2}=0.01, P \gg 0.1$.

wind strength increased. At the same time, the relative humidity of the surface atmosphere above the Southeast Pacific increased. Increased dominance of this relatively humid moisture source would provide a plausible explanation for falling DJF deuterium excess values at Punta Arenas.

However, this trend does not on its own explain the recent rise in summertime $\delta_{\mathrm{p}}$-values at Punta Arenas. Precipitation on the windward side of the Andes in the mid-latitudes has increased in response to strengthened zonal flow during the late twentieth and early twenty-first centuries (Garreaud, 2007). On their leeward side, an enhanced isotopic rain shadow effect should have resulted from increased rainout of the heavier isotopes on the windward flank of the Andes (Rozanski, 1995; Stern and Blisniuk, 2002). The moisture that penetrated to the leeward side should therefore have become relatively more depleted in $\delta^{18} \mathrm{O}$, similar to an enhanced continentality effect (Gat, 1980; Rozanski et al., 1993; Araguás-Araguás et al., 2000). Theoretically, however, this would have resulted in falling $\delta_{\mathrm{p}}$-values at Punta Arenas, 

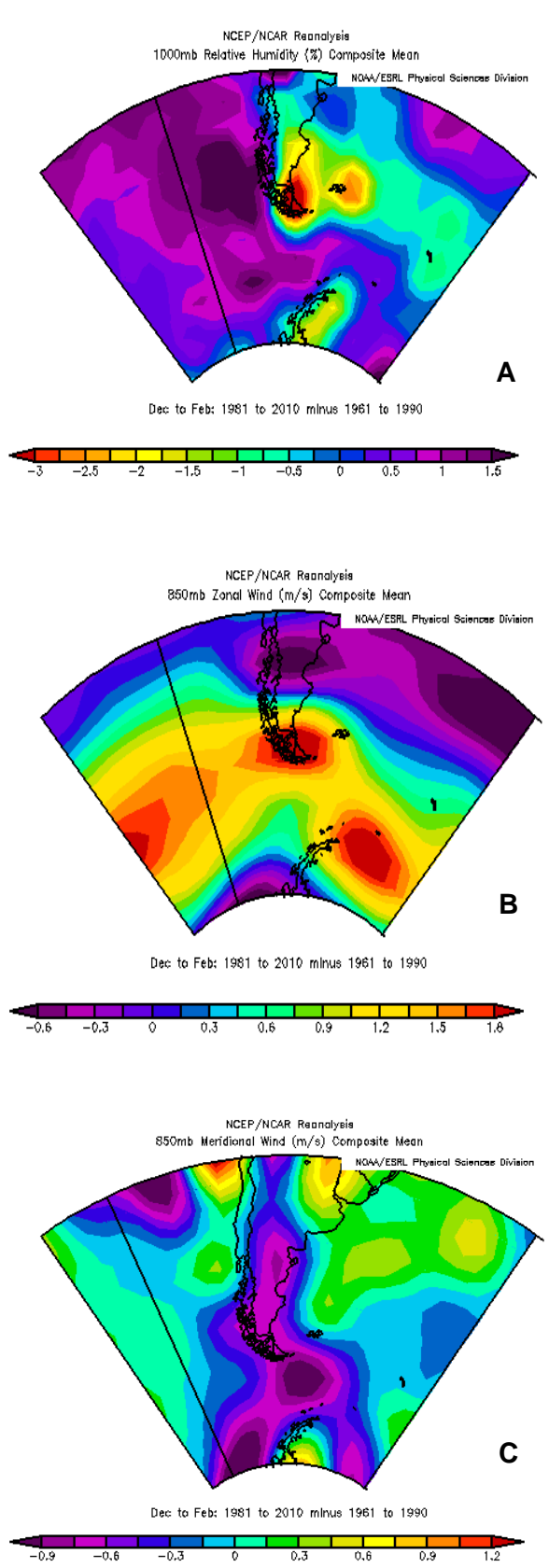

Fig. 7. The 1981-2010 anomaly relative to the 1961-1990 average for (A) $1000 \mathrm{mb}$ relative humidity (\%), (B) the $850 \mathrm{mb}$ zonal wind component $\left(\mathrm{m} \mathrm{s}^{-1}\right)$, and $(\mathbf{C})$ the $850 \mathrm{mb}$ meridional wind component $\left(\mathrm{ms}^{-1}\right)$. Positive values are from the west for the zonal $(u)$ component and from the south for the meridional $(v)$ component. Basic images are provided by the NOAA/ESRL Physical Sciences Division, Boulder Colorado from http://www.esrl.noaa.gov/psd/.

in marked contrast to the observations. The measured rise in $\delta_{\mathrm{p}}$-values could have resulted from the effects of adiabatic heating along a line closer to the dry lapse rate than that experienced previously, or from enhanced evaporation of falling raindrops in drier air (Gat, 1996; Friedman et al., 2002a, b).
In the study of modern waters by Stern and Blisniuk (2002), however, an upturn in $\delta_{\mathrm{p}}$-values was observed further downwind from the main isotopic rain shadow. This was attributed to a greater influence of northerly or South Atlantic air masses. Figure 7c shows that increased penetration of air from a more northerly (negative meridional component) direction has affected the study area. An alternative explanation, then, is that during the period 1981-2010, compared with 1961-1990, summer precipitation at Punta Arenas was increasingly derived from a more humid Southeast Pacific vapour source, carried by stronger westerly winds and subsequently mixed with an increased flow of warm air from the north, consistent with the documented southward shift in the mean westerly wind belt over this period (Thompson and Solomon, 2002; Marshall, 2003). The topographic profiles shown in Fig. 1 indicate that a stronger westerly wind component for the air masses affecting Punta Arenas would also have exposed them to a greater extent to a $\sim 50 \mathrm{~km}$ fetch of open sea due west of the city. If this sheltered stretch of water provided an additional moisture source for precipitation at Punta Arenas, $\delta_{\mathrm{p}}$-values could also rise, counteracting the isotopic rain shadow effect. Any effect on the deuterium excess values would depend on actual wind speeds, relative humidity above the water surface and local sea surface temperatures.

The lack of a similar rise in $\delta_{\mathrm{p}}$-values at Ushuaia in the 1990 s or 2000s can be attributed to differences in moisture source, and/or orographic and geographical setting (Fig. 1), between the two sites. The generally higher deuterium excess values for Ushuaia indicate a less humid vapour source, or one over which the relative humidity and surface air temperature have remained constant, but wind speeds have increased. This mismatch between the two sites poses a significant challenge for future studies and requires that more instrumental stable isotope data are collected to enhance the existing GNIP dataset.

The modern isotopic context presented here implies that careful consideration should be given to the interpretation of hydroclimatic and palaeoisotope records from the peatlands of Tierra del Fuego. Isotope theory and limited instrumental data suggest a link between the isotopic composition of precipitation and the characteristics of the moisture source from which it derives. In southern Patagonia, the observed patterns are noticeably different from those that would be recorded in the bogs of NE North America and NW Europe by virtue of the interaction of the $\mathrm{SH}$ westerlies with Andean topography. The modern measured $\delta \mathrm{D}$ and $\delta^{18} \mathrm{O}$-values of precipitation, whilst from relatively short records, suggest strong intra-regional variations. Were these fairly short-term trends to be captured in the annual increments of Sphagnum growth from nearby peat bog sites, the bogs near Punta Arenas would be expected to exhibit markedly different records from those near Ushuaia. The precise nature of those differences will, of course, depend on the specific topographical context of the peat bog site and its similarity to that of the 
GNIP stations from which the modern isotope data have been derived. However, the expectation of regional differences in the proxy records is valid.

It can be hypothesised, then, that where suitable peat bog sites are selected, it should be possible to associate mechanistically changes in the southern westerly wind belt (latitude and intensity) to variations in its hydroclimatic and stable isotopic "footprint" as recorded by a spatial array of peat bog sites over the late Holocene, in a similar fashion to that which has been undertaken already using spelothem archives (cf. McDermott et al., 2011). What is clear is the value of deuterium excess data. Significant extra-regional changes in the isotopic pathway from moisture source to precipitation should be detectable from variations in the deuterium excess, such that a southward latitudinal shift and zonal intensification of the westerlies should induce a fall in deuterium excess values in sites near Punta Arenas. Where past changes have involved variations in the intensity or latitude of the westerlies, the record of changes in a single isotope ratio (e.g. $\delta^{18} \mathrm{O}$ alone) may be insufficient to resolve ambiguities in the reconstructed atmospheric changes.

\section{Peatland palaeoclimate records from Tierra del Fuego}

Despite the potential for palaeoclimatic investigation of the Sphagnum bogs in Tierra del Fuego, relatively few records have been published to date. Palaeoecological records of estimated changes in past water table depth are available from macrofossil analyses of two peat profiles (AND-1 and AND2) from the Andorra Valley, $\sim 10 \mathrm{~km}$ to the northeast of Ushuaia, Tierra del Fuego, Argentina $\left(54^{\circ} 45^{\prime} \mathrm{S}, 68^{\circ} 18^{\prime} \mathrm{W}\right.$, ca. $180 \mathrm{~m}$ a.s.l.) (Mauquoy et al., 2004; Chambers et al., 2007). Palaeoisotope records from peat samples, largely dominated by Sphagnum magellanicum, have been published from Harberton Bog, east of Ushuaia $\left(54^{\circ} 53^{\prime} \mathrm{S}, 67^{\circ} 10^{\prime} \mathrm{W}\right.$, 20 ma.s.1.) (White et al., 1994; Pendall et al., 2001). The records from AND-1 and Harberton are shown in Fig. 8. The temporal resolutions of the data from AND-1 and Harberton Bog are sufficiently different to preclude a direct comparison of hydroclimatic and palaeo-isotope variation at these sites. Eleven ${ }^{14} \mathrm{C}$ ages are available for Harberton Bog, spanning the period after $3500 \mathrm{cal} \mathrm{BP}$, but six of these are conventional dates with low precision (as poor as $\pm 235 \mathrm{yr}$ ). All of the ${ }^{14} \mathrm{C}$ dates (13) for the AND-1 peat profile were measured by Accelerated Mass Spectrometry (AMS), but their time span is much shorter and covers the last $\sim 1400 \mathrm{cal}$ BP. Nonetheless, the data tentatively indicate that periods of drier (wetter) bog surface conditions at Andorra Bog were associated with relatively higher (lower) $\delta$ D-values in Sphagnum moss at Harberton Bog. Both bogs fall within the current climate space represented by the modern GNIP data from Ushuaia and show behaviour consistent with the pattern seen in the instrumental period, with increasing precipitation corresponding to

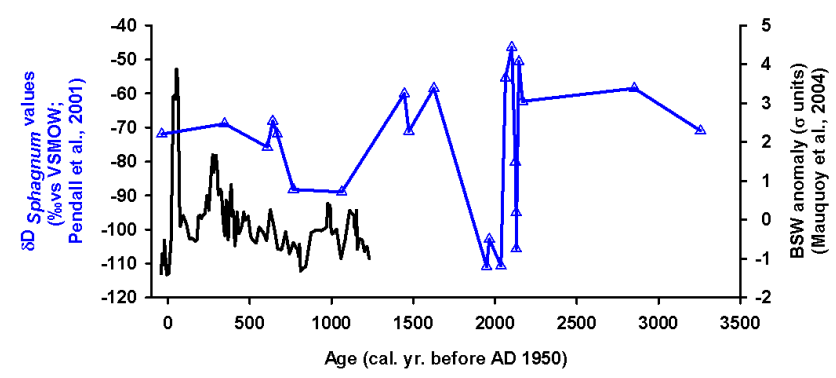

Fig. 8. Peatland hydroclimatic (AND-1; Mauquoy et al., 2004) and stable isotopic records (Harberton Bog; Pendall et al., 2001) from Tierra del Fuego. Blue line and triangles = palaeo stable isotope record from Harberton Bog. Black line = bog surface wetness reconstruction based on plant macrofossil data from Andorra Bog (more positive values indicate a drier bog surface).

lower $\delta_{\mathrm{p}}$-values. The lack of any supporting $\delta^{18} \mathrm{O}$ measurements prevents estimation of palaeo-d-values and hence past changes in moisture source region.

It has been argued, based on the palaeoecological records from Andorra Bog, that SH climate changes were synchronous with, and opposite in direction to, those in the Northern Hemisphere (Mauquoy et al., 2004; Chambers et al., 2007). The basal stratigraphy of a second profile from the same site (AND-2) records anomalously dry surface conditions, ${ }^{14} \mathrm{C}$ wiggle-match dated to $\sim 2820-2744$ cal BP (Chambers et al., 2007). This date range is also synchronous with an abrupt climate shift recorded in European mires (van Geel and Renssen, 1998; Speranza et al., 2002). The data we review here, however, differ in the range of mutiproxy evidence available, the precision of the age/depth models and the sampling resolution. Future analyses of raised Sphagnum bogs in Chile and Argentina need to be directed towards macrofossil, testate amoebae and stable isotope analyses (both $\delta^{18} \mathrm{O}$ and $\delta \mathrm{D}$ ), supported by high density ${ }^{14} \mathrm{C}$ chronologies. Once these data are available, it will be possible to identify with more certainty whether long-term Southern Hemisphere climate was in phase or antiphase (bipolar seesaw) with the Northern Hemisphere, and indeed how centennial to millennial scale variations in these parameters were set in the context of the general drying reported for southern South America over the past $\sim 500 \mathrm{yr}$ (Neukom et al., 2010).

\section{Conclusions}

Modern GNIP data indicate that the response of the isotopic composition of precipitation in southern South America to observed variations in the southern westerly wind belt in the last $\sim 20-30$ yr has been complex and geographically specific. At Punta Arenas and Ushuaia, isotope values in precipitation have varied in response to quite different trends in 
local surface air temperature and total precipitation amount. A recent fall in deuterium excess values associated with rising $\delta_{\mathrm{p}}$-values at Punta Arenas in austral summer is consistent with the observed southward shift and intensification of the zonal westerlies, accompanied by a smaller increase in the influence of air masses from the north. More substantive discussion of any further relationships is hampered by the incompleteness of the GNIP database for these locations.

Peat bog Sphagnum cellulose isotope data should be able to detect the changes in the isotopic composition of precipitation identifed in the GNIP data, but currently published records have insufficient temporal resolution to address this question. It is suggested that changes in the past $3000 \mathrm{yr}$, if associated with patterns of shifting latitudinal position and intensity of the westerlies, should be reflected in variations in the isotopic composition of the Sphagnum in sites near Punta Arenas and Ushuaia that depend mainly on any associated change in moisture source, detectable from the deuterium excess. Changes in the hydroclimatic regime will necessarily be driven by topographic context and by the relative amounts of moisture carried by the prevailing air masses. Peatlands offer an excellent archive for testing both the hydroclimatic and palaeoisotope variations. Isotopic techniques are now sufficiently advanced to open these archives to detailed investigation following the pioneering work of White et al. (1994), Mauquoy et al. (2004), Pendall et al. (2001) and Chambers et al. (2007). Developing records of sufficient temporal and spatial resolution to test this hypothesis inevitably sets the agenda for southern South American peat palaeoclimate research.

Acknowledgements. The authors would like to thank the UK Natural Environment Research Council (NERC grants NE/I022809/1, NE/I022833/1, NE/I022981/1 and NE/I023104/1) for financial support. We are grateful to three reviewers for their very helpful and supportive comments. We would also like to thank the staff of the GeoMapping Unit at Plymouth University for their tireless efforts in the production of figures for this manuscript.

Edited by: M. Grosjean

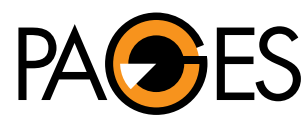

The publication of this article was sponsored by PAGES.

PAST GLOBAL CHANGES

\section{References}

Araguás-Araguás, L., Froehlich, K., and Rozanski, K.: Deuterium and oxygen-18 isotope composition of precipitation and atmospheric moisture, Hydrol. Process., 14, 1341-1355, 2000.

Barber, K. E.: Peat stratigraphy and climate change: A palaeoecological test of the theory of cyclic peat bog regeneration, Balkema, Rotterdam, 1981.
Barber, K. E. and Langdon, P. G.: What drives the peat-based palaeoclimate record? A critical test using multi-proxy climate records from northern Britain, Quaternary Sci. Rev., 26, 33183327, 2007.

Barber, K. E., Chambers, F. A., Maddy, D., Stoneman, R. E., and Brew, J. S.: A sensitive high-resolution record of Late Holocene climatic change from a raised bog in Northern England, Holocene, 4, 198-205, 1994.

Barber, K. E., Dumayne-Peaty, L., Hughes, P., Mauquoy, D., and Scaife, R.: Replicability and variability of the recent macrofossil and proxy-climate record from raised bogs: field stratigraphy and macrofossil data from Bolton Fell Moss and Walton Moss, Cumbria, England, J. Quaternary Sci., 13, 515-528, 1998.

Biester, H., Kilian, R., Franzen, C., Woda, C., Mangini, A., and Schöler, H. F.: Elevated mercury accumulation in a peat bog of the Magellanic Moorlands, Chile $\left(53^{\circ} \mathrm{S}\right)$ - An anthropogenic signal from the Southern Hemisphere, Earth Planet. Sc. Lett. 201, 609-620, 2002.

Björck, S., Rundgren, M., Ljung, K., Unkel, I., and Wallin, Å.: Multi-proxy analyses of a peat bog on Isla de los Estados, easternmost Tierra del Fuego: a unique record of the variable Southern Hemisphere Westerlies since the last deglaciation, Quaternary Sci. Rev., 42, 1-14, 2012.

Blundell, A. and Barber, K.: A 2800-year palaeoclimatic record from Tore Hill Moss, Strathspey, Scotland: the need for a multiproxy approach to peat-based climate reconstructions, Quaternary Sci. Rev., 24, 1261-1277, 2005.

Boettger, T., Haupt, M., Knöller, K., Weise, S. M., Waterhouse, J. S., Rinne, K. T., Loader, N. J., Sonninen, E., Jungner, H., MassonDelmotte, V., Stievenard, M., Guillemin, M. T., Pierre, M., Pazdur, A., Leuenberger, M., Filot, M., Saurer, M., Reynolds, C. E., Helle, G., and Schleser, G. H.: Wood Cellulose Preparation Methods and Mass Spectrometric Analyses of C-13, delta O-18, and nonexchangeable delta $\mathrm{H}-2$ values in cellulose, sugar, and starch: An interlaboratory comparison, Anal. Chem., 79, 46034612, 2007.

Boninsegna, J. A., Argollo, J., Aravena, J. C., Barichivich, J., Christie, D., Ferrero, M. E., Lara, A., Le Quesne, C., Luckman, B. H., Masiokas, M., Morales, M., Oliveira, J. M., Roig, F., Srur, A., and Villalba, R.: Dendroclimatological reconstructions in South America: A review, Palaeogeogr. Palaeocl., 281, 210-228, 2009.

Brenninkmeijer, C. A. M., van Geel, B., and Mook, W. G.: Variations in the $\mathrm{D} / \mathrm{H}$ and ${ }^{18} \mathrm{O} /{ }^{16} \mathrm{O}$ ratio in cellulose extracted from a peat core, Earth Planet. Sc. Lett., 61, 283-290, 1982.

Chambers, F. M., Mauquoy, D., Brain, S. A., Blaauw, M., and Daniell, J. R. G.: Globally synchronous climate change 2800 years ago: Proxy data from peat in South America, Earth Planet. Sc. Lett., 253, 439-444, 2007.

Chambers, F. M., Booth, R. K., De Vleeschouwer, F., Lamentowicz, M., Le Roux, G., Mauquoy, D., Nichols, J. E., and van Geel, B.: Development and refinement of proxy-climate indicators from peats, Quaternary Int., 268, 21-33, 2012.

Charman, D. J.: Summer water deficit variability controls on peatland water-table changes: implications for Holocene palaeoclimate reconstructions, The Holocene, 17, 217-227, 2007.

Charman, D. J., Blundell, A., Chiverrell, R. C., Hendon, D., and Langdon, P. G.: Compilation of non-annually resolved Holocene proxy climate records: stacked Holocene peatland palaeo-water 
table reconstructions from northern Britain, Quaternary Sci. Rev., 25, 336-350, 2006.

Charman, D. J., Barber, K. E., Blaauw, M., Langdon, P. G., Mauquoy, D., Daley, T. J., Hughes, P. D. M., and Karofeld, E.: Climate drivers for peatland palaeoclimate records, Quaternary Sci. Rev., 28, 1811-1819, 2009.

Clark, I. and Fritz, P.: Environmental Isotopes in Hydrogeology, Lewis Publishers, Boca Raton, 1997.

Clymo, R. S.: The Limits to Peat Bog Growth, Philos. T. Roy. Soc. B, 303, 1934-1990, doi:10.1098/rstb.1984.0072, 1984.

Clymo, R. S. and Hayward, P. M.: The ecology of Sphagnum, in: Bryophyte Ecology, edited by: Smith, A. J. E., Chapman Hall, London, 229-291, 1982.

Cole, J. E., Rind, D., Webb, R. S., Jouzel, J., and Healy, R.: Climatic controls on interannual variability of precipitation $\delta^{18} \mathrm{O}$ : Simulated influence of temperature, precipitation amount, and vapor source region, J. Geophys. Res.-Atmos., 104, 14223-14235, 1999.

Coronato, A., Roig, C., Collado, L., and Roig, F.: Geomorphologic emplacement and vegetation characteristics of Fuegian peatlands, southernmost Argentina, South America, in: Developments in Earth Surface Processes Peatlands Evolution and Records of Environmental and Climate Changes, edited by: Martini, I. P., Elsevier, Amsterdam, 111-128, 2006.

Craig, H.: Isotopic variations in meteoric waters, Science, 133, 1702-1703, 1961.

Daley, T. J. and Barber, K. E.: Multi-proxy Holocene palaeoclimate records from Walton Moss, northern England and Dosenmoor, northern Germany, assessed using three statistical approaches, Quaternary Int., 268, 111-127, 2012.

Daley, T. J., Street-Perrott, F. A., Loader, N. J., Barber, K. E., Hughes, P. D. M., Fisher, E. H., and Marshall, J. D.: Terrestrial climate signal of the " $8200 \mathrm{yr}$ B.P. cold event" in the Labrador Sea region, Geology, 37, 831-834, 2009.

Daley, T. J., Barber, K. E., Street-Perrott, F. A., Loader, N. J., Marshall, J. D., Crowley, S. F., and Fisher, E. H.: Holocene climate variability revealed by oxygen isotope analysis of Sphagnum cellulose from Walton Moss, northern England, Quaternary Sci. Rev., 29, 1590-1601, 2010.

Daley, T. J., Thomas, E. R., Holmes, J. A., Street-Perrott, F. A., Chapman, M. R., Tindall, J. C., Valdes, P. J., Loader, N. J., Marshall, J. D., Wolff, E. W., Hopley, P. J., Atkinson, T., Barber, K. E., Fisher, E. H., Robertson, I., Hughes, P. D. M., and Roberts, C. N.: The $8200 \mathrm{yr}$ BP cold event in stable isotope records from the North Atlantic region, Global Planet. Change, 79, 288-302, 2011.

Dansgaard, W.: Stable isotopes in precipitation, Tellus, 16, 436468, 1964

Darling, W. G. and Talbot, J. C.: The $\mathrm{O}$ and $\mathrm{H}$ stable isotope composition of freshwaters in the British Isles. 1. Rainfall, Hydrol. Earth Syst. Sci., 7, 163-181, doi:10.5194/hess-7-163-2003, 2003.

Dupont, L. M. and Brenninkmeijer, C. A. M.: Palaeobotanic and isotopic analysis of late Subboreal and early Subatlantic peat from Engbertsdijksveen-Vii, the Netherlands, Rev. Palaeobot. Palyno., 41, 241-247, 1984.

Filot, M. S., Leuenberger, M., Pazdur, A., and Boettger, T.: Rapid online equilibration method to determine the $\mathrm{D} / \mathrm{H}$ ratios of nonexchangeable hydrogen in cellulose, Rapid Commun. Mass Sp.,
20, 3337-3344, 2006.

Friedman, I., Harris, J. M., Smith, G. I., and Johnson, C. A.: Stable isotope composition of waters in the Great Basin, United States 1. Air-mass trajectories, J. Geophys. Res., 107, 4400, doi:10.1029/2001JD000565, 2002a.

Friedman, I., Smith, G. I., Johnson, C. A., and Moscati, R. J.: Stable isotope compositions of waters in the Great Basin, United States 2. Modern precipitation, J. Geophys. Res., 107, 4401, doi:10.1029/2001JD000566, 2002b.

Garreaud, R. D.: Precipitation and circulation covariability in the extratropics, J. Climate, 20, 4789-4797, 2007.

Garreaud, R. D.: The Andes climate and weather, Adv. Geosci., 22, 3-11, doi:10.5194/adgeo-22-3-2009, 2009.

Garreaud, R. D., Vuille, M., Compagnucci, R., and Marengo, J.: Present-day South American climate, Palaeogeogr. Palaeocl., 281, 180-195, 2009.

Gat, J. R.: The isotopes of oxygen and hydrogen in precipitation, in: Handbook of Environmental Isotope Geochemistry, edited by: Fritz, P. and Fontes, J. C., Elsevier, Amsterdam, 21-47, 1980.

Gat, J. R.: Oxygen and hydrogen isotopes in the hydrologic cycle, Annu. Rev. Earth Planet. Sc., 24, 225-262, 1996.

Gehre, M. and Strauch, G.: High-temperature elemental analysis and pyrolysis techniques for stable isotope analysis, Rapid Commun. Mass Sp., 17, 1497-1503, 2003.

Gong, D. and Wang, S.: Definition of Antarctic Oscillation index, Geophys. Res. Lett., 26, 459-462, 1999.

Huber, U. M., Markgraf, V., and Schäbitz, F.: Geographical and temporal trends in Late Quaternary fire histories of FuegoPatagonia, South America, Quaternary Sci. Rev., 23, 1079-1097, 2004.

Hughes, P. D. M., Blundell, A., Charman, D. J., Bartlett, S., Daniell, J. R. G., Wojatschke, A., and Chambers, F. M.: An 8500 cal. year multi-proxy climate record from a bog in eastern Newfoundland: contributions of meltwater discharge and solar forcing, Quaternary Sci. Rev., 25, 1208-1227, 2006.

IAEA/WMO: Global Network of Isotopes in Precipitation, the GNIP database, available at: http://isohis.iaea.org (last access: 15 January 2012), 2004.

Jones, J. M., Fogt, R. L., Widmann, M., Marshall, G. J., Jones, P. D., and Visbeck, M.: Historical SAM variability. Part I: Century-length seasonal reconstructions, J. Climate, 22, 53195345, 2009.

Jouzel, J., Alley, R. B., Cuffey, K. M., Dansgaard, W., Grootes, P., Hoffmann, G., Johnsen, S. J., Koster, R. D., Peel, D., Shuman, C. A., Stievenard, M., Stuiver, M., and White, J.: Validity of the temperature reconstruction from water isotopes in ice cores, J. Geophys. Res.-Oceans, 102, 26471-26487, 1997.

Jouzel, J., Hoffmann, G., Koster, R. D., and Masson, V.: Water isotopes in precipitation: data/model comparison for present-day and past climates, Quaternary Sci. Rev., 19, 363-379, 2000.

Jouzel, J., Stievenard, M., Johnsen, S. J., Landais, A., MassonDelmotte, V., Sveinbjornsdottir, A., Vimeux, F., von Grafenstein, U., and White, J. W. C.: The GRIP deuterium-excess record, Quaternary Sci. Rev., 26, 1-17, 2007.

Kidson, J. W.: Principal modes of Southern Hemisphere lowfrequency variability obtained from NCEP-NCAR reanalyses, J. Climate, 12, 2808-2830, 1999.

Kidston, J., Taschetto, A. S., Thompson, D. W. J., and England, M. H.: The influence of Southern Hemisphere sea-ice extent on the 
latitude of the mid-latitude jet stream, Geophys. Res. Lett., 38, L15804, doi:10.1029/2011GL048056, 2011.

Kilian, R., Hohner, M., Biester, H., Wallrabe-Adams, H. J., and Stern, C. R.: Holocene peat and lake sediment tephra record from the southernmost Chilean Andes (53-55- ${ }^{\circ}$ S), Revista geologica de Chile, 30, 23-37, 2003.

Langdon, P. G., Barber, K. E., and Hughes, P. D. M.: A 7500year peat-based palaeoclimatic reconstruction and evidence for an 1100-year cyclicity in bog surface wetness from Temple Hill Moss, Pentland Hills, southeast Scotland, Quaternary Sci. Rev., 22, 259-274, 2003.

Le Quéré, C., Rödenbeck, C., Buitenhuis, E. T., Conway, T. J., Langenfelds, R., Gomez, A., Labuschagne, C., Ramonet, M., Nakazawa, T., Metzl, N., Gillett, N., and Heimann, M.: Saturation of the southern ocean $\mathrm{CO}_{2}$ sink due to recent climate change, Science, 316, 1735-1738, 2007.

Leuenberger, M. C., Lang, C., and Schwander, J.: Delta(15)N measurements as a calibration tool for the paleothermometer and gasice age differences: A case study for the 8200 BP event on GRIP ice, J. Geophys. Res.-Atmos., 104, 22163-22170, 1999.

Limpasuvan, V. and Hartmann, D. L.: Eddies and the annular modes of climate variability, Geophys. Res. Lett., 26, 3133-3136, 1999.

Mark, A. F., Johnson, P. N., Dickinson, K. J. M., and McGlone, M. S.: Southern hemisphere patterned mires, with emphasis on southern New Zealand, J. Roy. Soc. New Zeal., 25, 23-54, 1995.

Markgraf, V.: Paleoenvironments and paleoclimates in Tierra del Fuego and southernmost Patagonia, South America, Palaeogeogr. Palaeocl., 102, 53-68, 1993.

Marshall, G. J.: Trends in the Southern Annular Mode from observations and reanalyses, J. Climate, 16, 4134-4143, 2003.

Martínez Cortizas, A., Biester, H., Mighall, T., and Bindler, R.: Climate-driven enrichment of pollutants in peatlands, Biogeosciences, 4, 905-911, doi:10.5194/bg-4-905-2007, 2007.

Mataloni, G.: Ecological studies on algal communities from Tierra del Fuego peat bogs, Hydrobiologia, 391, 157-171, 1998.

Mauquoy, D., Blaauw, M., van Geel, B., Borromei, A., Quattrocchio, M., Chambers, F. M., and Possnert, G.: Late Holocene climatic changes in Tierra del Fuego based on multiproxy analyses of peat deposits, Quaternary Res., 61, 148-158, 2004.

McDermott, F., Atkinson, T. C., Fairchild, I. J., Baldini, L. M., and Mattey, D. P.: A first evaluation of the spatial gradients in $\delta^{18} \mathrm{O}$ recorded by European Holocene speleothems, Global Planet. Change, 79, 275-287, 2011.

Ménot-Combes, G., Burns, S. J., and Leuenberger, M.: Variations of ${ }^{18} \mathrm{O} /{ }^{16} \mathrm{O}$ in plants from temperate peat bogs (Switzerland): implications for paleoclimatic studies, Earth Planet. Sc. Lett., 202, 419-434, 2002.

Merlivat, L. and Jouzel, J.: Global Climatic Interpretation of the Deuterium-Oxygen-18 Relationship for Precipitation, J. Geophys. Res.-Oceans, 84, 5029-5033, 1979.

Moore, D. M.: Flora of Tierra del Fuego, Antony Nelson, Oswestry, 1983.

Moreno, P. I., François, J. P., Villa-Martínez, R. P., and Moy, C. M.: Millennial-scale variability in Southern Hemisphere westerly wind activity over the last 5000 years in SW Patagonia, Quaternary Sci. Rev., 28, 25-38, 2009.

Moy, C. M., Dunbar, R. B., Moreno, P. I., Francois, J. P., VillaMartínez, R., Mucciarone, D. M., Guilderson, T. P., and Garreaud, R. D.: Isotopic evidence for hydrologic change related to the westerlies in SW Patagonia, Chile, during the last millennium, Quaternary Sci. Rev., 27, 1335-1349, 2008.

Neukom, R., Luterbacher, J., Villalba, R., Küttel, M., Frank, D., Jones, P. D., Grosjean, M., Esper, J., Lopez, L., and Wanner, H.: Multi-centennial summer and winter precipitation variability in southern South America, Geophys. Res. Lett., 37, L14708, doi:10.1029/2010GL043680, 2010.

Neukom, R., Luterbacher, J., Villalba, R., Küttel, M., Frank, D., Jones, P., Grosjean, M., Wanner, H., Aravena, J. C., Black, D., Christie, D., D’Arrigo, R., Lara, A., Morales, M., Soliz-Gamboa, C., Srur, A., Urrutia, R., and von Gunten, L.: Multiproxy summer and winter surface air temperature field reconstructions for southern South America covering the past centuries, Clim. Dynam., 37, 35-51, 2011.

Pendall, E., Markgraf, V., White, J. W. C., Dreier, M., and Kenny, R.: Multiproxy record of late Pleistocene-Holocene climate and vegetation changes from a peat bog in Patagonia, Quaternary Res., 55, 168-178, 2001.

Petoukhov, V. and Semenov, V. A.: A link between reduced Barents-Kara sea ice and cold winter extremes over northern continents, J. Geophys. Res.-Atmos., 115, D21111, doi:10.1029/2009JD013568, 2010.

Roig, F., Roig, C., Rabassa, J., and Boninsegna, J.: Fuegian floating tree-ring chronology from subfossil Nothofagus wood, Holocene, 6, 469-476, 1996.

Rojas, M., Moreno, P., Kageyama, M., Crucifix, M., Hewitt, C., beOuchi, A., Ohgaito, R., Brady, E. C., and Hope, P.: The Southern Westerlies during the last glacial maximum in PMIP2 simulations, Clim. Dynam., 32, 525-548, 2009.

Rozanski, K.: Deuterium and O-18 in European Groundwaters Links to Atmospheric Circulation in the Past, Chem. Geol., 52, 349-363, 1985.

Rozanski, K.: Spatial and temporal variability of stable isotope composition of precipitation over the south american continent, Bulletin de l'Institut francais d'études Andins, 24, 379-390, 1995.

Rozanski, K., Araguas-Araguas, L., and Gonfiantini, R.: Relation between long-term trends of oxygen-18 isotope composition of precipitation and climate, Science, 258, 981-985, 1992.

Rozanski, K., Araguas-Araguas, L., and Gonfiantini, R.: Isotopic patterns in modern global precipitation, Climate Change in Continental Isotopic Records, 1-36, 1993.

Sapkota, A., Cheburkin, A. K., Bonani, G., and Shotyk, W.: Six millennia of atmospheric dust deposition in southern South America (Isla Navarino, Chile), Holocene, 17, 561-572, 2007.

Siegenthaler, U. and Oeschger, H.: Correlation of ${ }^{18} \mathrm{O}$ in precipitation with temperature and altitude, Nature, 285, 314-317, 1980.

Sonntag, C., Rozanski, K., Munnich, K. O., and Jacob, H.: Variations of deuterium and oxygen-18 in continental precipitation and groundwater and their causes, in: Variations in the Global Water Budget, edited by: Street-Perrott, F. A., D. Reidel Publishing Company, Dordrecht, 107-124, 1983.

Speranza, A., van Geel, B., and van der Plicht, J.: Evidence for solar forcing of climate change at ca. $850 \mathrm{cal}$ BC from a Czech peat sequence, Global Planet. Change, 35, 51-65, 2002.

Stern, L. A. and Blisniuk, P. M.: Stable isotope composition of precipitation across the southern Patagonian Andes, J. Geophys. Res., 107, 4667, doi:10.1029/2002JD002509, 2002. 
Swindles, G. T., Morris, P. J., Baird, A. J., Blaauw, M., and Plunkett, G.: Ecohydrological feedbacks confound peat-based climate reconstructions, Geophys. Res. Lett., 39, L11401, doi:10.1029/2012GL051500, 2012.

Thompson, D. W. J. and Solomon, S.: Interpretation of recent Southern Hemisphere climate change, Science, 296, 895-899, 2002.

Toggweiler, J. R. and Russell, J.: Ocean circulation in a warming climate, Nature, 451, 286-288, 2008.

van Geel, B. and Middeldorp, A. A.: Vegetational history of Carbury bog (Co. Kildare, Ireland) during the last 850 years and a test of the temperature indicator value of ${ }^{2} \mathrm{H} /{ }^{1} \mathrm{H}$ measurements of peat samples in relation to historical sources and meteorological data, New Phytol., 109, 377-392, 1988.

van Geel, B. and Renssen, H.: Abrupt climatic change around 2,650 BP in north-west Europe: Evidence for climatic teleconnections and a tentative explanation, in: Water, environment and society in times of climatic change, edited by: Issar, A. S. and Brown, N., Kluwer, Amsterdam, 1998.
Varma, V., Prange, M., Lamy, F., Merkel, U., and Schulz, M.: Solarforced shifts of the Southern Hemisphere Westerlies during the Holocene, Clim. Past, 7, 339-347, doi:10.5194/cp-7-339-2011, 2011.

Vimeux, F., Ginot, P., Schwikowski, M., Vuille, M., Hoffmann, G., Thompson, L. G., and Schotterer, U.: Climate variability during the last 1000 years inferred from Andean ice cores: A review of methodology and recent results, Palaeogeogr. Palaeocl., 281, 229-241, 2009.

White, J. W. C., Ciais, P., Figge, R. A., Kenny, R., and Markgraf, V.: A High-Resolution Record of Atmospheric $\mathrm{CO}_{2}$ Content from Carbon Isotopes in Peat, Nature, 367, 153-156, 1994. 